Gynecol. Obstet. Invest. 1982;13:I-IV

\title{
Contents, Vol. 13, 1982
}

\section{Contents Vol. 13,1982}

\section{No. 1 Original Paper}

Bacteriologic Aspects of Pelvic Inflammatory Disease in Gynecologic Patients

Creatsas, G.K.; Pavlatos, M.P.; Koumantakis, E.; Zolotas, J.; Kaskarelis, D.B

Paradoxical Hypersecretion of Growth Hormone in Patients with Endometrial Atypical

Hyperplasia and Carcinoma. Effect of Hysterectomy

Ayalon, D.; Peyser, M.R.; Limor, R.; Lessing, J.B.; Ravid, R 9

Metabolic Studies in Gestational Diabetic Women during Contraceptive Treatment: Effects on Glucose Tolerance and Fatty Acid Composition of Serum Lipids

Rådberg, T.; Gustafson, A.; Skryten, A.; Karlsson, K 17

Antagonism by PGE2 of the Vasoconstriction Induced by PGF2 $\alpha$ in Human Ovary in

vitro

Varga, B.; Zsolnai, B 30

In vitro Aromatization of Androgens into Estrogens in Placental Insufficiency

Thoumsin, H.J.; Alsat, E.; Cedard, L 37

Terbutaline and Pulmonary Surfactant Release in the Rabbit Fetus

Bergman, B.; Hedner, T.; Samsioe, G

Elective Cervical Suture of Twin Pregnancies Diagnosed Ultrasonically in the First Trimes ter following Induced Ovulation

Dor, J.; Shalev, J.; Mashiach, S.; Blankstein, J.; Serr, D.M 55

Book Reviews 61

Announcement 64

No. 2 Original Paper

Evaluation of Various Monitoring Techniques in Late Pregnancy to Detect Poor Intrauterine Fetal Growth

Pavelka, R.; Schmid, R.; Reinold, E 65

Long-Term Therapy with Subcutaneous Heparin during Pregnancy

Hellgren, M.; Nygårds, E.-B 76

Ultrasonic Examination before External Version of Breech Presentation

Kirkinen, P.; Ylöstalo, P 90

Identification of Women with Significant Fear of Childbirth during Late Pregnancy

Areskog, B.; Kjessler, B.; Uddenberg, N 98

Metergoline in the Management of Hyperprolactinemic Amenorrhea and Anovulation

Falsetti, L.; Voltolini, A.M.; Crosignani, P.G.; Lotti, G.; Travaglini, P.; Faglia, G.;

Cianci, A.; Palumbo, G.; Praga, C; Pontiroli, A.E 108

Lipid Metabolic Studies in Oophorectomized Women: Effects of Synthetic Progestogens on Individual Serum Phospholipids and Serum Lecithin Fatty Acid Composition

Silfverstolpe, G.; Samsioe, G.; Svanborg, A.; Gustafson, A 117

Book Reviews

127 
Contents III

No. 3 Original Paper

Amniotic Fluid Beta-2-Microglobulin in Normal and Complicated Pregnancies. Correlation with Gestational Age, Creatinine Concentration and L/S Ratio

Puolakka, J.; Ylöstalo, P.; Tuimala, R.; Haapalahti, J.; Järvinen, P.A 129

Comparison between Serum Levels of Oestriol in Venous and Capillary Blood from Pregnant

Women

Axelsson, O.; Hofstedt, M.; Tegeman, A.; Wide, L 135

Smooth Muscle Antibodies in Pre-Eclampsia of Pregnancy

Pietarinen, I.; Kivinen, S.; Ylöstalo, P.; Mäkitalo, R.; Laakso, L 142

Effect of Amnioscopy on Concentrations of Prostaglandin F2 $\alpha$, Prostacylcin and Thromboxane in Maternal Plasma

Ylikorkala, O.; Viinikka, L 150

Opioid Plasma Levels during Labour

Facchinetti, F.; Centini, G.; Parrini, D.; Petraglia, F.; D’Antona, N.; Cosmi, E.V.;

Genazzani, A.R 155

Ultrastructural Changes in Preputial Neural Tissues: Effects of Maternal Smoking

Amankwah, K.S; Weberg, A.D 164

Fetal Death in utero: Effect on Estrone, Estradiol-17ß and Progesterone Levels in the Ewe

Abrams, R.M.; Kalra, P.S.; Clapp, J.F. 111; Wilcox, C.J.; Carter, R.L 177

Current Investigation

Decreased Adenosine 3',5'-Cyclic Monophosphate Concentration in Amniotic Fluid during

Rivanol-Induced Abortion

Bistoletti, P.; Ölund, A.; Lunell, N.-O.; Fredholm, B184

Book Reviews 189

No. 4 Original Paper

Diagnostic and Therapeutic Viewpoints on Cervical Intraepithelial Neoplasia. 10-Year Follow-Up of a Conization Material

Andersch, B.; Moinian, M 193

Steroid Receptors in Normal and Neoplastic Female Reproductive Tissues

Saarikoski, S.; Selander, K.; Kallio, S.; Pystynen, P 206

Are the Histological and Ultrastructural Features of Endometrial Carcinomas Reliable Indicators

of Their Steroid Receptor Content?

Genton, C.Y.; Büchi, K.A 213

A Statistical Approach to the Determination of the Fertile Period

Carter, R.L.; Abrams, R.M.; Moghissi, K.S 226

Basal Body Temperature as a Method of Ovulation Detection: Comparison with Ultrasonographical Findings

Wetzels, L.C.G.; Hoogland, H.J.; Haan, J. de 235

Correlation of Birth Weights with Umbilical Cord Serum LH-hCG, FSH, ß-hCG, Estradiol,

Cortisol and Testosterone Levels

Furuhashi, N.; Fukaya, T.; Kono, H.; Tachibana, Y.; Shinkawa, O.; Takahashi, T. . 241

Immunological Observations on the Relationship of SPia to SPiß

Ahmed, A.G.; Klopper, A 249

IV

Contents 
Technique for Stepwise Reduction of Uterine Blood Flow in the Chronically Prepared Preg nant Sheep

Yafl $1 \frac{1}{8}$, H.; Katz, M.; Parer, J.T 257

Current Investigation

Urinary Mucopolysaccharide Excretion in Women with Pelvic Inflammatory Disease

Gorodeski, I.G.; Neri, A.; Wasserman, L.; Bahari, CM 261

Book Review 264

Author Index 266

Subject Index 267

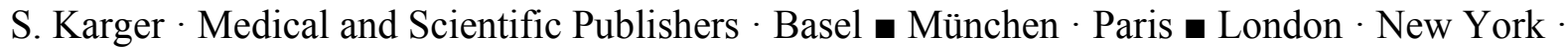
Tokyo $\cdot$ Sydney

Drug Dosage

The authors and the publisher have exerted every effort to ensure that drug selection and dosage set forth in this text are in accord with current recommendations and practice at the time of publication. However, in view of ongoing research, changes in government regulations, and the constant flow of information relating to drug therapy and drug reactions, the reader is urged to check the package insert for each drug for any change in indications and dosage and for added warnings and precautions. This is particularly important when the recommended agent is a new and/or infrequently employed drug.

All rights reserved.

No part of this publication may be translated into other languages, reproduced or utilized in any form or by any means, electronic or mechanical, including photocopying, recording, microcopying, or by any information storage and retrieval system, without permission in writing from the publisher.

S. Karger AG, P.O. Box, CH-4009 Basel (Switzerland) Printed in Switzerland by Thür AG Offsetdruck, Pratteln 